\title{
IJAAR

\section{ROLE OF DISCIPLINE AND ITS IMPACTS ON LEARNING PROCESS AND EDUCATION STANDARD IN IBARAPA NORTH LOCAL GOVERNMENT, OYO STATE}

\author{
ADEYEMO, AYUBA OLABODE \\ Department of Curriculum \& Instruction, \\ The College of Education, Lanlate, Oyo State, Nigeria. \\ Email: Ayubaolabode@gmail.com
}

\begin{abstract}
The main purpose of this study is to investigate the effects and roles of discipline on learning process and education standard in Ibarapa North Local Government, Oyo State. Learning process of the student has received little attention in relation to discipline. A total of two hundred students randomly selected from six out of the nine senior secondary schools (i.e 67\%) in the town were used for the study. Questionnaires were used to collect data on discipline and learning process of the students. For the analysis of data, frequency count, simple percentage, $t$ test and ANOVA were used. The study revealed that discipline starts with the teachers and the school environment in relation to learning process. Not only this, home is also an agent of discipline for the students or wards through provision of necessary materials for school activities. This provides a learning process for the students when they felt they were satisfied.
\end{abstract}

Keywords: Discipline, learning process, education, indiscipline. 


\section{Introduction}

The key driver or force for effective quality performance of any organization or system is workforce discipline. In all organizations, whether they are serving private or public interest have a corporate mission or purpose. The attainment of this mission guarantees the organization's survival, growth and acceptability to its numerous stakeholders. In the school system or academic environment, it is impossible to achieve better production of teacher and good performance without discipline. For the on-going needs of qualified teachers and efficient trained good student to be achieved, specific orders and discipline should be maintained and followed to the latter as one of the most potent drivers or forces for the production of standard teachers and learners. Standard education is the only remedy to ignorance. And this can be achieved through effective discipline of teachers, learners in the learning environment.

Discipline improves smooth and efficient management of the school and administrators. Discipline in school system helps to produce well behaved male and female students who do not only respect themselves but also the school authorities and regulations of the school. Discipline is very essential for creating a positive school climate conducive to learning process and sound academic performance and achievement. Ali et al (2014) opine that a disciplined student is one whose behaviours, actions and inactions conform to the predetermined rules and regulations of the school organisation. Discipline is an essential ingredient for successful teaching and learning process in school environment and an element of concern for school teachers.

Kennedy et al. (2018) have identified children as future asset that serves as potential human resource which needs to replace the old ones in the near generation. They stressed further that for this to come to realization, it is important to ensure that these younger generations are well disciplined to remain focused in life. Act of moral decadence both among the students and teachers has eroded good values and behaviour causing decline in the standard of education and the core values. According to Maphosa and Mammen (2011), learners in school of today are noted for disrespecting authorities, going to school late, fighting among themselves, refusing to do homework and dressing indecently. These acts of indiscipline in schools do not make environment to be conducive for learning but leads to poor concentration on the part of learners. In all, discipline ensures the safety of students and teachers, even all other staff in the school system and make environment to be conducive for learning.

The school, which is an integral part of entire society, achieves its goals and objectives through teaching and learning process. Good learning process and effective education can only be achieved if only both students and staff comply with the rules and regulations. Therefore, discipline of both students and staff is a precondition for effective teaching and learning to take place (Adesope, 2015).

Akinboye (2000) says that discipline in any organizational set up has been recognized by many eminent professional administrators as a most dependable parameter for the measurement of the operational success of that system. Good and effective discipline is, in fact, the life blood of any system. Discipline is the first law in a good school, without it, success cannot be 
achieved. In a disorderly school or class, the teacher loses inspiration and likewise the students pay little or no attention to instruction.

Discipline in school or learning environment ensures safety of staff and students and creates an environment conducive for learning and for acquiring skills useful for self-reliance in future. Where there is discipline, order of the day will be secured and obeyed. The teachers or instructors find it easy to gain the attention of the learners while presenting their ideas to the students and the students in turn will be able to comprehend what the teachers are teaching. Well disciplined persons, group or nation can only receive normal or quality education for growth and development. Education is a panacea for a vast range of tasks, a dynamic instrument of change and tool for growth and development. Scort (2014) opines that education is an instrument that can change the destiny of any nation. It is a necessity for learning process to be easy and conducive, and orderliness should be the watch-word in the school system. The National Policy on Education (2014) stresses that education should be functional, relevant, practical and geared towards the acquisition of appropriate skills and the development of competencies as equipment for individuals to live and contribute to the development of the society. No school system can achieve success or good record in learning process unless there is maintenance and development of discipline in school environment. Improvement in learning process and education of the learners is a vital tool for attaining good performance for the learners.

Orderliness or discipline in school system is very important for students for acquisition of skills during learning process. Education without discipline cannot be easy. Discipline, which is the set of rules, orders and regulations reminding us of the proper code of behaviour helps in school education. Discipline, not only in school life, is very important in all facets of life for self-improvement. It assists individual to achieve his/her goals in life.

\section{Concept of Discipline}

Being well mannered is the fruit of knowledge. The proper functioning of any system or organization mostly requires some rules and regulation of the members of the organization. Discipline is very pertinent and crucial in school environment for the learning process to take effect smoothly. For the performance of students to be standard, they need to conform to the rules or conditions that are conducive to learning. Discipline is characterized by a particular, unique academic and social style (quoted in Strand, 2007). Discipline is a way of maintaining orders in a given environment or system, especially the school system. Gough (1953) says that no academic institution can achieve control of the students without attaining a high standard of discipline and good moral.

While forcing learners to obey rules and orders, the school administrators must strictly ensure that the school clearly maintains the disciplined environment that promotes teaching and learning. The growth and sustainability of academic and scientific knowledge resulted in a proliferation of academic disciplines that have the continuity to grow. The effect of this growth and expansion of discipline in higher education is the way the colleges of education and universities are functionally and properly organized into departments and schools. Afolabi et al (1992) view discipline as a decent and decorous conduct, and exalted sense of responsibility, 
respect for authority, love for orderliness, eagerness to discharge duties with promptitude and efficiency. Discipline is a way of policing certain behaviours or way of thinking. Discipline in form of self-control which leads to good behaviour without any external control fosters stability in educational settings that paves way for qualitative education (Fayambo and Ogunsanya, 2005).

Yadar \& Lakshmi (1995) point out that discipline is a deliberate differentiation of the knowledge base with a specific perspective in order to gain better understanding of the phenomenon under focus. To them, knowledge base represents the sum total of the human understanding of environment. Effective maintenance of orders in a specific environment or system like school system helps improving learning process of both learners and instructors.

Dogan (2001) refers to discipline as organizational units in educational programmes, that is, in schools and organizational units in knowledge production. Discipline can be seen as a branch of instruction that is useful for the transmission of knowledge which is the convenient mapping of academic administration. It is (discipline) a technical term for improving and organizing learning for the systematic production of new knowledge.

\section{Things that Weaken Discipline in School System}

There are so many things done that weaken the rules and orders in both the organization and school system. Among them are:

$>\quad$ Inability to walk the talk". It means not engaging in any illegal doings or immoral doings that may appear not to constitute direct havoc to schools e.g becoming a contraction to your establishment by proxy, indecent relationship with a staff, member or student in school.

$>$ Corrupt practices by the heads that staff often uncovers becomes a challenge to the administration of discipline.

$>\quad$ Inability to be fair to all i.e lack of equity consideration or double standard.

Fostering discipline in school environment for the growth of learning process in a positive way, an administrator or instructor needs to encourage positive behaviour using reward and likewise honesty among the staff and students.

\section{Factors Improving Discipline in School System}

Durosaro \& Ogunsaju (2000) have highlighted some factors contributing to effective discipline in school.

i. Teacher's modeling and personality: To acquire desirable behaviour from tutors or elders, modeling is very useful and should be a continuous operation to instill in children the discipline or useful orders. The presence and appearance helps a lot for the student to be orderly and obedient. The character of the teacher is another key factor that serves as impetus to students for them to be diligent and progress intellectually and morally. 
ii. Communication is another way of maintaining discipline in any system. Delivering of necessary information to appropriate quarters helps to obey rules and boosts the morale of the learners or concern body.

iii. Method of teaching: Teaching intelligent students and availability of facilities though very important, if the method used by the teacher is ineffective, the success of the lesson may be hampered. Therefore, learners will show signs of restlessness. Good teaching method helps to sustain students' attention, obey order and maintain discipline.

iv. Constant involvement of the students in school activities helps to maintain discipline.

v. Reinforcement is a useful discipline strategy when we want to strengthen a desirable behaviour that is weakly manifested in the child or learner.

vi. Conducive learning environment: Any physical discomfort at times disturbs the concentration and attention of the students. Serious attention needs to be paid to good ventilation so that great heat is not allowed to lower the students' vitality.

vii. Student-Community relations: School system should institute a policy where teachers are required to contact parents periodically. This helps to a certain extent to reduce indiscipline among their wards.

Learning process (teaching): The primary aim of education is the perfection of the individual for self-reliance and productivity in the society. The teacher should understand the objective he/she wishes to fulfill as this determines the means and method to adopt in maintaining discipline in the school system. Education is the training of the mind and the development of a virtuous character which takes place gradually through learning process or teaching. Perfection of learning process only occurs in school system by well-disciplined teachers and in a conducive learning environment. Learning is a process not the actual product. In actual fact, learning is the process of acquiring or receiving new, or modification of existing knowledge, behaviours, skills, values, attitudes and preferences. This acquisition of new idea or renewal of past behaviours largely depends on having orderliness in a giving learning environment. Therefore, learning process is the process that people pass through to gain new knowledge and skills which ultimately affect their attitudes, decisions and actions in life. It is an activity carried to achieve educational objectives.

The ability the teacher, head of school or school administrator must have to orchestrate differentiated learning process or instruction, everyday by assessing the learners and adjustment of strategies and tactics requires well-disciplined environment and skillful personnel. To successfully gain the attention of learners during learning process, the teachers or school administrators must have a firm understanding of each of the learners' interest and needs, for them to comply with the rules and regulations, believing they have been catered for. Discipline can be improved during learning process if the school administrators or class teachers develop a rich repertoire of strategies and tactics that can address the specific breakdown for a specific task at the right time. To engage, motivate and teach or instruct all learners at optimal levels, the class teachers need to understand the learning process in all and respond to students' individual emotional and cognitive profiles and select instructional strategies that are effective for diverse 
learners. This is an avenue or method of developing discipline in learning environment that assist learning process.

Paying attention is the first step in learning process. Learners pay attention to things that are interesting or exciting to them. If it is not interesting to them, they become distracted and create disorderliness and element of indiscipline crop up. The class teacher's job is to construct, manage and maintain a condusive learning environment in term of discipline. It is wise for the teacher to find acceptable, non-destructive ways for the learners to be active. Learners usually obey or follow the rules if their needs are addressed and ready to learn.

\section{Acts of Indiscipline as Destructive Factors to Learning Process in Educational Setting}

Many factors are really responsible for indiscipline in educational settings. The behaviour, value and characteristics of learners usually reflect the society in which they are brought up. Most of these causes of indiscipline are mostly traceable to parents at home, school heads, teachers in the school, the government and general public.

Home factors: Many parents have abandoned the responsibility of taking care of their children. Olusakin (2004) observes that some parents have little or no time for the children who are often left in the care of house helps. Some house helps may not bother to take care of the children properly and these children pick up the behaviour of the helpers which they exhibit in school. Even many parents are not disciplined too in terms of moral behaviour. In the words of Sokan and Akinade (2006), parental styles of child rearing such as authoritarian and permissive methods of child upbringing breed children who lack discipline.

The permissive parents who set inconsistent standards produce children that will lack self-confidence and who are delinquency prone. These parents normally engage in over protection and over permissiveness. When the children of the parents get to school, they break rules because of self-control, lack of home support, absence of safety and security, lack supervision and intellectual inspiration (Ogunsaya, 2003).

School factors: Some of act stages are: the school personnel's indiscipline like having element of stringent rules, teachers' lackadaisical attitudes to work, indecent dressing and illicit relationship with students, failure in preparing for the work, failure of school to have cordial relationship with the staff and maintenance of high integrity and failure to discharge leadership role. Other areas are poor school environment, illegal collection of fees, teachers' absenteeism from school or class, giving preferential treatment to female student e.t.c

Poor or irregular funding of educational setting is another cause of indiscipline in school system. This may lead to irregular payment of teachers' salaries and students' negative attitude to schooling. Reorganisation and retrenchment of workers cause indiscipline in school and society. Students are part of the general society, they use to imitate what the adult would do, hence the various acts of indiscipline in schools that often make the learning environment unstable, making teaching and learning process ineffective. 


\section{Statement of the Problem}

The standard of learning process in the country is in shambles and the rate of acquiring basic skills in teaching and learning process by the students is declining everyday in the class. Poor concentration and inattentiveness affect the learning process of the students today in the learning environment. Indiscipline among students that needs to be reduced by the school administrators may be responsible for poor concentration of students and may lead to poor academic performance.

Because of positive effect of discipline on learning process and education in general, learning environment or school system in order to salvage poor concentration of students resulting to poor performance, there is need to consider factors affecting learning process during teaching or when discharging instructions.

\section{Purpose of the Study}

The purpose of the study is to assess of the role of discipline factor on learning process or teaching. Specifically, the paper is to assess the basic components of discipline for helping and assisting the teaching learning process. Also, it is to assess the disciplined student or disciplined class for full concentration during learning process. The paper examines the effect of indiscipline on learning process where the environment is not palatable for receiving instruction.

\section{Research Question}

What is the perception of Senior Secondary School students in Ibarapa North, Oyo State on effect of discipline and its role on learning process?

\section{Hypotheses}

$\mathrm{Ho}_{1}$ : There is no significant difference in the perception of male and female Senior Secondary School students in Ibarapa North in the influence of discipline on learning process.

Ho2: There is no significant difference in the perception of male and female students in rural and urban secondary schools on role of discipline on learning process.

Ho3: There is no significant difference in the perception of private and public secondary school students in Ibarapa North on role of discipline on learning process.

\section{Scope of the Study}

The study focused on the role of the discipline on teaching and learning process in the school system. The researcher wanted to assess discipline based teachers and learners as it affects their performance, productivity and learning rate of the learners.

\section{Methodology}

The population consists of the Senior Secondary Schools from both the private and public schools in Ibarapa North Local Government, Oyo State. Simple random sampling 
technique was employed in the selection of six (6) Senior Secondary Schools from private and public senior secondary schools. For the collection of data, the researcher used self-developed questionnaire titled, 'Factors Affecting Effective Discipline and Learning Process' (FAEDP). It was 20 items designed as 4 point likert type scale. Validity of the instrument was established given to expert for correction and amendment. Also test-retest reliability was used in order to determine the consistency of the instrument. Pearson product correlation co-efficient was employed to analyse the result, 0.85 reliability was obtained. The data collected was analysed using t-test and ANOVA statistical method.

\section{Research Question}

What is the perception of senior secondary school students in Ibarapa North Local Government, Oyo State on effects of discipline and its role on learning process?

Table 1

\begin{tabular}{|c|c|c|c|c|c|}
\hline $\mathbf{S} / \mathbf{N}$ & Factors & Accept & $\%$ & Reject & $\%$ \\
\hline 1. & Teaching in untidy environment & 102 & 60 & 72 & 40 \\
\hline 2. & $\begin{array}{l}\text { Teacher's method of teaching improves } \\
\text { understanding and discipline }\end{array}$ & 107 & 80 & 75 & 20 \\
\hline 3. & Instructional material is not inadequate for teaching & 102 & 55 & 85 & 45 \\
\hline 4. & Class sitting arrangement is poor & 127 & 70 & 54 & 30 \\
\hline 5. & Maintenance of physical facilities is poor & 80 & 45 & 100 & 55 \\
\hline 6. & Poor ventilation affects learning & 95 & 55 & 86 & 45 \\
\hline 7. & Building not well located & 110 & 60 & 72 & 40 \\
\hline 8. & Provision for students relaxation centre is poor & 145 & 82 & 38 & 18 \\
\hline 9. & $\begin{array}{l}\text { Provision for teachers' relaxation centre is } \\
\text { inconducive }\end{array}$ & 140 & 84 & 30 & 16 \\
\hline 10. & Bias in disciplining students & 145 & 80 & 45 & 20 \\
\hline 11. & $\begin{array}{l}\text { Poor monitoring/supervision by local and state } \\
\text { ministry of education }\end{array}$ & 139 & 75 & 50 & 25 \\
\hline 12. & Recruitment strategies are poor & 160 & 90 & 20 & 10 \\
\hline 13. & Poor finding & 150 & 80 & 38 & 20 \\
\hline 14. & $\begin{array}{l}\text { Teachers' attitude and behaviour toward teaching in } \\
\text { the class }\end{array}$ & 150 & 87 & 26 & 13 \\
\hline 15. & Teachers' punctuality improves discipline & 113 & 80 & 29 & 20 \\
\hline 16. & $\begin{array}{l}\text { Immoral relationship between teachers and student } \\
\text { causes chaos }\end{array}$ & 82 & 98 & 2 & 2 \\
\hline 17. & $\begin{array}{l}\text { Students not participating in extra and co-curricular } \\
\text { activities causes indiscipline }\end{array}$ & 130 & 72 & 51 & 28 \\
\hline 18. & Teacher's mode of dressing & 117 & 63 & 68 & 37 \\
\hline 19. & Teachers aid and abet examination malpractices & 29 & 20 & 145 & 80 \\
\hline 20. & $\begin{array}{l}\text { Teachers patriotism, resourcefulness and honesty aid } \\
\text { discipline many students }\end{array}$ & 160 & 89 & 20 & 11 \\
\hline
\end{tabular}


It has been shown from table 1 that factors listed above are accepted with the exception of item 5. This indicates that students believe that their learning process are being affected by discipline and even maintain the code of conduct by the teachers. $80 \%$ agreed that teacher's method of teaching improves understanding and discipline, while $70 \%$ agreed that sitting arrangement is poor and affect learning process in the classroom cause indiscipline. Likewise $60 \%$ and $82 \%$ agreed that building is not well located and students' relaxation centre is poor respectively. This causes students not to obey the rules and regulations and disorderliness occurs. $80 \%$ agree that there is bias and nepotism in discipline the students. This results in disobedience by the students. Looking at the table, it was observed that teachers' punctuality regularly improves discipline. $98 \%$ agreed that immoral relationship between male teachers and female students caused disobedience and violation of rules and regulations. 89\% also agreed that teacher's patriotism, resourcefulness and honesty aid discipline.

Ho: There is no significant difference in the perception of male and female Senior Secondary School students in Ibarapa North in the influence of discipline on learning process and teaching.

Table 2: T-test comparing the means and standard deviation of Ibarapa North Local Government students of Senior Secondary School on the perception of students on influence of discipline in learning process.

\begin{tabular}{|l|c|c|c|c|c|}
\hline \multicolumn{1}{|c|}{ Sex } & Mean & Student deviation & t-calculated & t-tab & Remarks \\
\cline { 1 - 2 } Male & 2.0911 & 0.95824 & \multirow{2}{*}{2.361} & \multirow{2}{*}{0.18} & Accept \\
\cline { 1 - 3 } Female & 2.0070 & 0.97645 & & Ho \\
\hline
\end{tabular}

It was revealed from the table that there is no significant different between the perception of male and female Senior Secondary School students on influence of discipline in learning process. The t-table value is 0.19 which is less than the level of significance.

$\mathrm{Ho}_{2}$ : There is no significant difference in the perception of male and female students in rural and urban secondary schools on the role of discipline in learning process.

Table 3: Analysis of variance comparing the perception of male and female students in rural and urban schools on influence of discipline in learning process.

\begin{tabular}{|c|c|c|c|c|c|}
\hline & Sum of Square & Df & Mean Square & F & Significant \\
\hline Between groups & 14.262 & 2 & 7.115 & \multirow{2}{*}{6.765} & \multirow{2}{*}{.001} \\
\cline { 1 - 4 } Within groups & 3636.876 & 3676 & 1.028 & & \\
\hline \multicolumn{1}{|c|}{ Total } & $\mathbf{3 6 5 1 . 1 3 8}$ & $\mathbf{3 6 7 8}$ & & & \\
\hline
\end{tabular}

From the table, it shows that f-value 6.765 is greater than the critical of 0.001 at 0.05 level of significance. This implies that the perception of students on the influence of discipline on learning process on the location of school is not the same or equal. 
Ho3: There is no significant difference in the perception of Ibarapa North private and public secondary school students on effect of discipline on learning process.

Table 4: T-test comparing the perception of the private and public schools students on effect of discipline on learning process.

\begin{tabular}{|l|c|c|c|c|}
\hline Variance & Mean & Student Deviation & t-tabulated & t-calculated \\
\hline Public & 2.0705 & 1.01632 & \multirow{2}{*}{0.348} & 0.935 \\
\hline Private & 2.0475 & 1.01677 & & \\
\hline
\end{tabular}

In table 4 above, the t-tabulated (0.348) is lower the t-calculated (0.935) at 0.05 level of significance. It shows that there is no significant difference in the perception of students from private and public secondary schools on the influence of discipline on learning process. Therefore, the hypothesis (1) is accepted.

\section{Discussion of Findings}

Table 1 on frequency count and simple percentage of the effect of discipline on learning process, the findings from the table revealed that items 3, 4, 6, 7, 8, and 9 that have the percentage of acceptance as 55\%, 70\%, 55\%, 60\%, 82\% and 84\% respectively show that factors that influence learning process emanate from school environment, which are inadequate material from the school, classroom seating arrangement, poor ventilation, location of school, student relaxation centre, and teachers relaxation centre.

In supporting this assertion, Edward (2007) says that many problems associated with discipline are normal reactions by the children to deficiencies in the school environment and to the teachers and administrators of educational sector. He further states that teachers can give way to issues of indiscipline if they misunderstand learning conditions and require students to learn information that is not meaningful to them. Krashen (1985) also believes that the school environment has a great role to play if students are to be encouraged to obey the rules and regulations of the school.

Results from the table also shows that items 11, 14, 15 and 16 which have $75 \%, 87 \%$, $80 \%$ and $98 \%$ respectively show that monitoring, teachers' attitudes, punctuality and immoral behaviour by the teachers have great influence on learning process of student.

This was supported by Adeyemi (2015) who says that punctuality and teachers' cordial relationship with students assist to identify students problem and assist them and relief them and have opportunity to have full concentration on learning.

From the analysis in table 2, the result shows that there is no significant difference in the perception of the male students and female students on the effect of discipline on learning process. This means that gender of the students does not necessarily influence learning process through effective discipline. 
Also in table 3, the results reveal that there is no significant difference on the effect of discipline on learning process or teaching from urban environment and rural area from which students came from. This is due to a thin line that exists between the urban and rural area of the town.

Table 4 reveals that there is no significant difference in the feeling of student from private and public schools on the effect of discipline on teaching learning process. The result indicates that the school attended will not significantly affect students' rate of obeying the rules and regulations of the school environment which invariably affect their learning.

\section{Conclusion}

The study examined the roles of discipline on learning process and education standard of Senior Secondary Schools in Ibarapa North, Oyo State. Specifically, the study looked at the effect of discipline on learning process which can influence education standard. The study also looked at the effects of parents and teachers' way of disciplining students. The common indiscipline acts committed by the teachers in the study area are immoral relationship, lateness to school or absenteeism, examination malpractices, unpreparedness for teaching, poor method of teaching e.t.c.

On the part of students are failure to respect the rules and regulations of the schools, failure to do homework, assault to colleagues etc. From the result, discipline has a positive relationship with learning process and quality education in Ibarapa North, Oyo State.

\section{Recommendations}

In this study, teachers or school administrators and students were the major instruments to improve discipline in school environment. Therefore, teachers and students relationship should be cordial to eliminate hatred but to instill love. School-community relationship is also important in building appropriate discipline. This is due to opportunity given to parent to resist school regularly. Mostly Parent-Teacher Association meetings can be of help to share idea of checking indiscipline in the schools. Teachers need to upgrade themselves in their teaching methodologies and serve as role model in the area of dressing, immoral relationship with the students. Good communication should be an instrument by the head teachers to pass information to appropriate channel as and when due. Good monitoring strategies, especially internal monitoring should be put in place in the school environment. Government should try as much as possible to ensure that the monitoring team move around during school day to check roaming of students on the street during school hours. To have great turn around in students' learning process and improvement on standard education, government should get rid of touts who incessantly pollute the society with hard drugs and immoral activities. 


\section{References}

Adeyemi, I. O. (2015). Employee Training and Development A tool for Self-Reliance and Sustainability Development; International Journal of Social and Policy Issues.

Afolabi, F. O. \& Adeboyeje, R. (1992).Basic Concepts I n School Administration and Suspension. Ondo. Yaba.

Akinboye, J. O. (2000). Psychology of Discipline in Contemporary Nigerian, Education.Journal of Nigerian Education Research Council, Vol. 1, 113-122.

Ali, A. A.; Dada, I. T. \&Isiaka, G. A. (2014).Types, Causes and management of indiscipline acts among secondary school students in Shomolu Local Government Area of Lagos State.Journal of Studies in Social Sciences, 8 (2).Retrieved from http://www.infinitypress.info./index.php/jsss/article/download/790/379.

Dogan, M. (2001).Specialization and Recombination of Specialties in the Social Sciences. In International Encyclopedia of Social and Behavioural Sciences: London, PergamonElsevier Science.

Fayambo, G. A. \&Ogunsanya, e. a. (2005). Discipline in Schools in S. Y. Erinoso et al (Eds.) Issues in School organization. Lagos: African Institute.

Federal Republic of Nigeria (2014).National Policy on Education, Abuja, Federal Ministry of Education Press.

Gough, H G. (1953). What determines the academic achievement of High School Students.Journal of Educational Research, 46 (5).

Kennedy, N. O. \& Godwin, T. (2018). The Effects of Indiscipline on Academic performance of Junior High School Students in the Fanteakwa District of Ghana. Journal of Education and Practice, Vol. 9 no. 21. Retrieved from www.iiste.org

Krashen, S. (1985).“A model of second language performance”. Paper presented at the winter meeting of the Linguistic Society of America, San Franscisco, 1975.

Maphosa, C. \& Mammen, K. J. (2011). How chaotic and unmanageable classroom have become: Insight into prevalent forms of learner indiscipline in South African Schools. The Anthropologist, 13 (3), 195-193.

Ogunsaju, S. (2003). Educational Supervision Perspectives and Practice in Nigeria. Ile-Ife: Obafemi Awolowo University Press.

Olusakin, A. M. (2004). Stealing among Students; Causes and Remedies in O. E. Obe (Ed.) School Indiscipline and Remedial. Enugu: Premier Publishers.

Scort, S. O. (2014). Promoting Vocational and Technical Education for National Development. Journal of Research in Vocational and Technical Education, 2 (1) 71-88.

Sokan, B. O. \& Akinade, E. A. (2006).Developmental Psychology. A basic text for Colleges and Universities, Ibadan: Catalog Publications Nigeria Ltd. 